\title{
The Evaluation of Alkali Grass (Puccinellia ciliata Bor) Populations in Aydin Province of Turkey
}

\author{
İlkay $\operatorname{Yavaş}^{1 *}$ Aydın Ünay², Serap Şimşek ${ }^{2}$ \\ ${ }^{I}$ Department of Plant and Animal Production, Kocarli Vocational High School, Adnan Menderes University,09100 Aydin, Turkey \\ ${ }^{2}$ Department of Field Crops, Faculty of Agriculture, Adnan Menderes University, 09100 Aydin, Turkey
}

\section{A R T I C LE IN F O}

\section{Research Article}

Received 01 December 2016

Accepted 16 March 2017

\section{Keywords:}

Puccinellia ciliata Bor

Hyperaccumulator

Phytoremediation

Translocation factor

Enrichment factor

\section{Corresponding Author:}

E-mail: iyavas@adu.edu.tr

\begin{abstract}
A B S T R A C T
Alkali grass grows in waterlogged, saline and alaline soils. The main problem in these soils is minerals at toxic level. The toxic ions are chloride, sodium and boron. A number of techniques have been investigated for removing toxic metals from the soil. Today, the cost-effective and environmentally technique is phytoremediation, using hyperaccumulator plants. Alkali grass (Puccinellia ciliata Bor) is suggested as a hyperaccumulator plant by the combination of more favourable characteristics with salt and waterlogging tolerance, high biomass value and convincing nutritive value for adverse environmental conditions. For this reason, we collected alkali grass and soil samples from five different locations in Aydın-Muğla highway, Turanlar and Sinırteke villages in Germencik-Aydın. In the soil analysis, we observed that $\mathrm{K}$ accumulation varies between root, shoot and panicle at least whereas $\mathrm{Na}$ and $\mathrm{B}$ shows more variation on whole plant portions among locations. Intense aerenchyma development on the root tips of Puccinellia plant was observed and it is determined as radial lysogenic aerenchyma formation. Average plant height and dry matter values were between 47.2-74.4 cm and 15.61-80.85 g/plant according to locations. The highest plant height value was obtained from the first location whereas the highest dry matter yield was detected in the fifth location. In conclusion, plants from fifth location can be regarded as fodder plants in these areas. Our results indicated that alkali grass can be effective for phytoextraction of sodium and boron from contaminated sites.
\end{abstract}

DOI: https://doi.org/10.24925/turjaf.v5i8.858-863.1114

\section{Introduction}

The presence of toxic metals in soil and water has a negative impact on human, environment and agriculture. Instead of using pricy traditional remediation techniques for improvement of heavy metals-contaminated areas, researchers focused on cost-effective, sustainable and eco-friendly technique called phytoremediation. This thriving method is using specially selected and engineered metal accumulating plants in the name of environmental clean up (Salt et al., 1995).

When particular ions accumulated in the leaves of plant during water transpiration at a certain level via soil water uptake, the plants suffer from toxicity. The degree of the damage depends on growing stage, ion concentration, plant sensitivity and water consumption. The damage can be severe enough to cause loss of production. Phytoextraction is the most promising approach in removal of toxic heavy metals from the soil, by using hyperaccumulator plants. They accumulate and detoxify higher quantities of metal ions in their aboveground parts and can survive under metal (Kachout et al., 2009; Marques et al., 2009; Nazir et al., 2011; Paz-
Ferreiro et al., 2014). In order to perform the objectives of phytoremediation technique, the selected hyperaccumulator plants must have some abilities as well as accumulating higher amounts of toxic metal ions in the target area.

According to numerous researchers, there are some important criteria in selecting a hyperaccumulator plant for phytoremediation; being adaptive to adverse environmental conditions (e.g., waterlogging, high $\mathrm{pH}$, salinity, etc.), having tolerance to the heavy metal toxicity, the level of heavy metal ion accumulation, translocation and uptake potential, having high biomass value, high growth rate, depth of root zone, root characteristics, being available in various habitats; terrestrial, aquatic, semi aquatic etc. (LeDuc et al., 2005; Pilon-Smits, 2005; Sarma, 2011).

Especially in Aegean region of Turkey agricultural areas irrigated with surface water is contaminated with boron significantly. The high salt and boron levels reduce yields of many of the selected crops. One of the most important factors affecting the amount of boron in the soil 
is the amount of $\mathrm{CaCO}_{3}$. There is a negative relationship between the boron intake of plants and amount of water soluble $\mathrm{Ca}$ in the soil. Precautions against boron toxicity are considered temporary and inadequate. For this reason, the best action to tolerate boron toxicity is the usage of boron tolerant plants.

Alkali grass is a native plant to Turkey. It is a member of the Poacea family. "Menemen" is the only cultivar collected fom the Kaklıç village near to Menemen (where the cultivars name came from Menemen province-İzmir). It was stated that alkali grass is a perennial bunch grass with $40 \mathrm{~cm}$ tall, tolerant to salinity, moderate to high with an EC range 5 to $40 \mathrm{dS} / \mathrm{m}$ (Barret-Lennard, 2003). Plant has a great waterlogging tolerance and also tolerates submergence conditions. It can live in soil conditions where soil $\mathrm{pH}$ values range from 5.5 to 8.0. It has also high drought and frost tolerance. Alkali grass has a convincing nutrititive value during winter and early spring and has good dry matter digestibility (DMD) (60$78 \%$ ) and protein (10-18\%) values in winter and early spring. The plant is usually sown as a pioneer plant for soil erosion control or soil restoring of saltlands in South Australia and it is marketed in South Australia as "restora sweet grass". As a salt tolerant plant, Alkali grass has low salt content, makes it ideal for supplementary feed for stock.

The aim of this study was to reveal the cultivation of the hypercumulator plant such as Puccinellia distans which is tolerance to boron and its ability to accumulate it in its tissues and economical value of uncultivated areas is a good solution. Therefore Puccinellia ciliata Bor was considered a suitable plant for this work

\section{Material and Methods}

\section{Sample Collection Procedure}

Alkali grass (Puccinellia ciliata Bor) and the soil samples were collected prior to surveys from five different locations in this study. The coordinates of locations were $37^{\circ} 48^{\prime} \mathrm{N}-27^{\circ} 50 \mathrm{E}$ for location I, in AydınMugla railway $6 . \mathrm{km}, 37^{\circ} 81^{\prime} \mathrm{N}-27^{\circ} 63^{\prime} \mathrm{E}$ for location II, $37^{\circ} 82^{\prime} \mathrm{N}-27^{\circ} 64^{\prime} \mathrm{E}$ for location III, $37^{\circ} 83^{\prime} \mathrm{N}-27^{\circ} 65^{\prime} \mathrm{E}$ for location IV and $37^{\circ} 83^{\prime} \mathrm{N}-27^{\circ} 67^{\prime} \mathrm{E}$ for location $\mathrm{V}$ in Turanlar/ Sinırteke (Figure 1). At each location, four randomly samples were collected for a total of 20 soil samples (4 samples $\times 5$ locations). Also, the Puccinellia plant samples were collected at the stage of panicle during April and May.

\section{Soil Analyses}

Soil characterizations and heavy metal concentrations in different locations were analyzed according to Wolf (1971) and observed in Table 1.

\section{Plant Characteristics}

Plant height was measured from the plant base to the tip of the panicle and mean values were expressed in centimeter. Green herbage yields were determined by weighing the harvested plants from each location. $0.5 \mathrm{~g}$ of wet samples were taken from each location for dry hay yield. And the samples were stored at $70^{\circ} \mathrm{C}$ for 48 hours in a drying cabinet. Dry hay yield values were obtained from multpliying green hay yield and dry hay ratio.

Table 1 Soil characterizations in different locations where Puccinellia ciliata (Bor) plant shows wide distribution in Aydin.

\begin{tabular}{|c|c|c|c|c|c|c|c|c|c|c|}
\hline \multirow{2}{*}{ Properties } & \multirow{2}{*}{\multicolumn{2}{|c|}{$\begin{array}{c}\text { Location I } \\
\text { Explanation }\end{array}$}} & \multirow{2}{*}{\multicolumn{2}{|c|}{$\begin{array}{c}\text { Location II } \\
\text { Explanation }\end{array}$}} & \multirow{2}{*}{\multicolumn{2}{|c|}{$\begin{array}{l}\text { Location III } \\
\text { Explanation }\end{array}$}} & \multirow{2}{*}{\multicolumn{2}{|c|}{$\begin{array}{l}\text { Location IV } \\
\text { Explanation }\end{array}$}} & \multirow{2}{*}{\multicolumn{2}{|c|}{$\begin{array}{l}\text { Location V } \\
\text { Explanation }\end{array}$}} \\
\hline & & & & & & & & & & \\
\hline Structure & $\mathrm{L}$ & Loam & $\mathrm{C}$ & Clay & $\mathrm{L}$ & Loam & $\mathrm{L}$ & Loam & SICL & SCL \\
\hline Sand $(\%)$ & 48.57 & & 24.42 & & 48.16 & & 32.96 & & 10.61 & \\
\hline Silt (\%) & 36.43 & & 29.26 & & 37.09 & & 43.77 & & 58.99 & \\
\hline Clay (\%) & 15.00 & & 46.32 & & 14.75 & & 23.27 & & 30.40 & \\
\hline Satur. (\%) & 42.1 & & 122.8 & & 39.5 & & 58.5 & & 47.4 & \\
\hline Org.Matter. & 1.01 & Low & 0.95 & Very Low & 0.59 & Very Low & 0.30 & Very Low & 0.30 & Very Low \\
\hline $\mathrm{pH}$ & 9.19 & K. Alkaline & 8.91 & K. Alkaline & 8.31 & Alkaline & 10.39 & K. Alkaline & 10.83 & K. Alkaline \\
\hline Lime & 7.87 & High & 13.93 & High & 7.57 & High & 8.48 & High & 20.89 & Excessive \\
\hline Salt & 0.0897 & Salt-free & 0.1418 & Salt-free & 0.0887 & Salt-free & 0.1198 & Salt-free & 0.1447 & Salt-free \\
\hline $\mathrm{P}(\mathrm{ppm})$ & 18 & Medium & 13 & Medium & 5.40 & Low & 12 & Medium & 20 & High \\
\hline $\mathrm{K}(\mathrm{ppm})$ & 446 & Very high & 457 & Very high & 342 & Very high & 224 & Medium & 352 & Very high \\
\hline $\mathrm{Ca}(\mathrm{ppm})$ & 2256 & Medium & 2845 & Medium & 2453 & Medium & 2354 & Medium & 1962 & Medium \\
\hline $\mathrm{Mg}(\mathrm{ppm})$ & 242 & High & 1328 & Very high & 1347 & Very high & 462 & Very high & 131 & Medium \\
\hline $\mathrm{Na}(\mathrm{ppm})$ & 1301 & Very high & 3234 & Very high & 1237 & Very high & 3435 & Very high & 5479 & Very high \\
\hline $\mathrm{Fe}(\mathrm{ppm})$ & 25.52 & High & 53.34 & High & 19.82 & High & 40.54 & High & 38.02 & High \\
\hline $\mathrm{Zn}(\mathrm{ppm})$ & 0.90 & Critical & 0.68 & Critical & 0.86 & Critical & 0.60 & Critical & 0.56 & Critical \\
\hline $\mathrm{Mn}(\mathrm{ppm})$ & 13.72 & Adequate & 10.44 & Adequate & 11.32 & Adequate & 9.08 & Adequate & 6.74 & Adequate \\
\hline $\mathrm{Cu}(\mathrm{ppm})$ & 1.70 & Adequate & 2.28 & Adequate & 3.30 & Adequate & 2.00 & Adequate & 1.46 & Adequate \\
\hline $\mathrm{B}(\mathrm{ppm})$ & 8.62 & Toxic & 5.65 & Adequate & 6.00 & Toxic & 14.47 & Toxic & 13.74 & Toxic \\
\hline
\end{tabular}

SCL: Silty Clay Loam 


\section{Calculation of Hyperaccumulation Criteria}

The definition of metal hyperaccumulation requires the consideration of metal concentrations in the aboveground biomass and the soil. Both the enrichment factor (EF) and the translocation factor (TF) have to be considered when determining whether a particular plant is a metal hyperaccumulator. The enrichment factor is calculated as the ratio of the plant shoot concentration to the soil concentration ([Metal $]_{\text {shoot }} /[\text { Metal }]_{\text {soil }}$ ), while the translocation factor is the ratio of the metal concentration in the shoot to that in the root ([Metal $]_{\text {shoot }} /[\text { Metal }]_{\text {root }}$ ). A hyperaccumulator plant should possess an EF or TF $>1$ (Kutty and Al-Mahaqeri, 2016).

\section{Statistical Analysis}

The basic parameters such as mean, standart error and cofficient of variation values were analyzed using the TARİST statistical program (Açıkgöz et al., 1994)

\section{Results}

\section{Soil Characterization}

Table 1 given that soil characteristics of different locations where Alkali grass shows wide distribution in Aydin. According to the analysis, soils showed different structures; in I. III. and IV. locations soils were loam, in the II. location it was clay and in the V. location it was silty clay loam. Saturation values $(\%)$ of these locations ranged from 39.5-122.8 and generally found to be very low in organic matter. $\mathrm{pH}$ values were changed from 8.31 to 10.83 . Soil samples from each location varied in $\mathrm{P}$ levels and differ between low and high values. While $\mathrm{K}$ values were generally very high, $\mathrm{Ca}$ values were moderate and $\mathrm{Mg}$ was generally defined as high-very high. Despite the presence of low levels of salt, very high level of $\mathrm{Na}$ examined and this could be interpreted as an indication of sodic soils of these areas. As Fe was found in high levels,
$\mathrm{Zn}$ was found to be critical in all areas. The amount of $\mathrm{Mn}$ and $\mathrm{Cu}$ were adequate. The $\mathrm{B}$ values ranged from 5.6514.47 and is often found to be on toxic levels.

When the soil characteristics were evaluated it could said that Puccinellia ciliata Bor plant shows propagation on the areas which are usually low in organic matter, having excess alkali values, high sodium problem, and the toxic levels of B. (Table 1).

\section{Plant Nutrition Contents}

Plants collected from different locations randomly. Plant nutrition contents $(\mathrm{Na}, \mathrm{K}, \mathrm{Ca}, \mathrm{Mg}$ and $\mathrm{B})$ per root, stem and cluster are given in the Table 2. Plant Na, K, Ca, $\mathrm{Mg}$ analyzes were determined according to Kacar (2009) and B analyze was stated according to Wolf (1971) with Azomethin-H method. The amounts of $\mathrm{Na}$ and $\mathrm{B}$ accumulated in root tissue were $35.25 \%$ and $31.22 \%$, respectively. $\mathrm{Na}$ values of parameters were changed from $0.09 \%$ to $0.26 \%$, B values ranged from 449 to $1078 \mathrm{ppm}$. $\mathrm{K}$ and $\mathrm{Mg}$ values which had the coefficient of variation below $10 \%$ had shown mean values of 0.18 and 0.70 respectively. Similar changes occured in $\mathrm{Ca}$ values which were ranged from 0.66 to 1.13 . Location IV showed much more accumulation except $\mathrm{Na}$ in the name of accumulation. When the accumulation in stems examined, we observed that the accumulation of all elements except $\mathrm{K}$ showed variation. The accumulation of $\mathrm{K}$ was $0.93 \%$ on average. $\mathrm{Na}$ accumulation was 0.09 to $0.43 \%$; $\mathrm{Ca}$ accumulation was 0.18 to $0.30 \%, \mathrm{Mg}$ accumulation was 0.14 to $12.27 \%$, and B values ranged from 64 to $816 \mathrm{ppm}$, respectively. Location IV showed much more accumulation except $\mathrm{Mg}$ in terms of accumulation. Cluster showed a variation between locations in terms of all elements. Na accumulation was 0.03 to $0.14 \%, \mathrm{~K}$ was 0.25 to $0.35 \%, \mathrm{Ca}$ accumulation was 0.09 to $0.18 \%, \mathrm{Mg}$ accumulation was 0.18 to $0.34 \%$, and $\mathrm{B}$ values ranged from 169 to $794 \mathrm{ppm}$, respectively (Table 2).

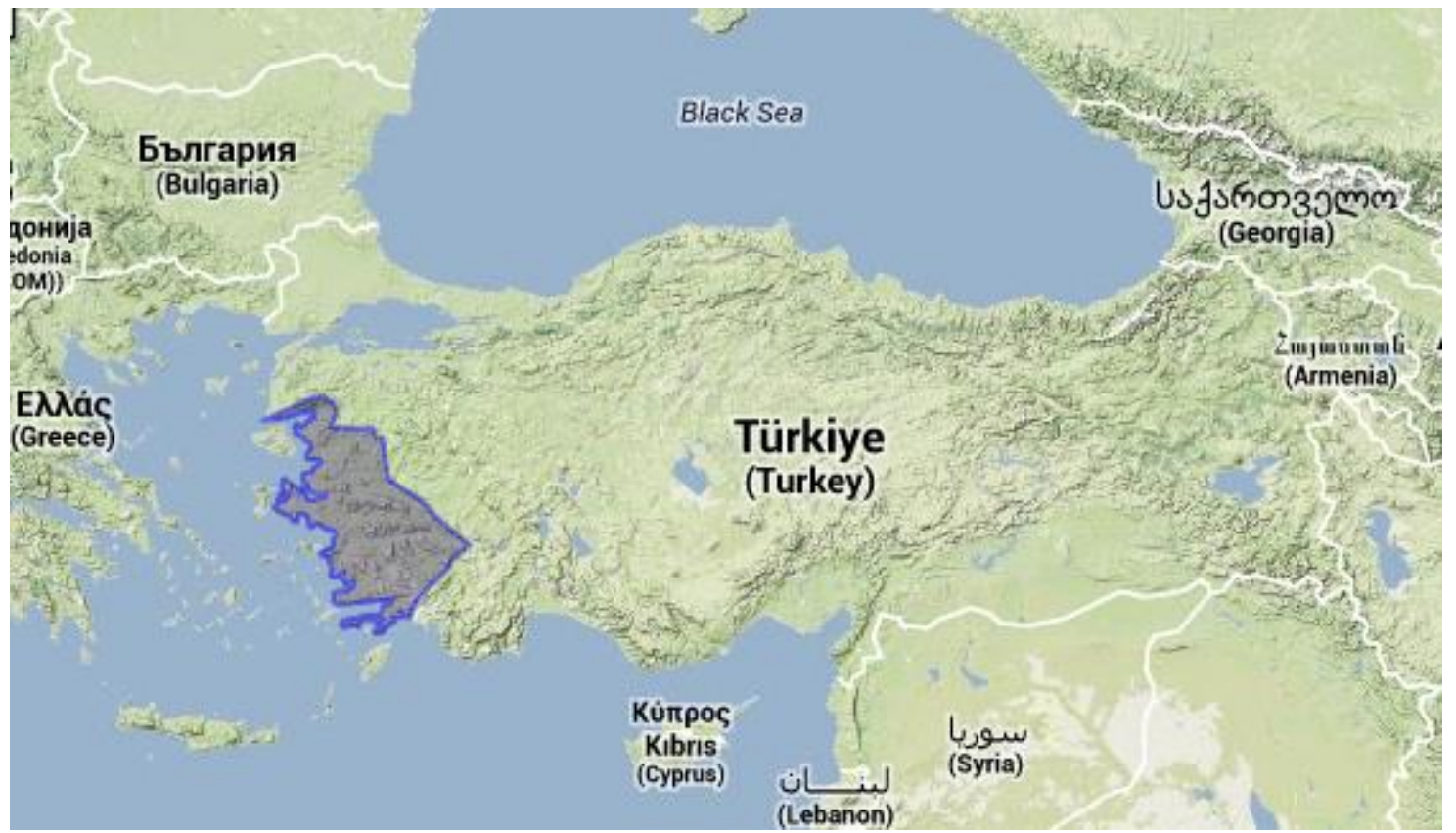

Figure 1 Puccinellia ciliata distribution in Aegian Reagion of Turkey 
Location I
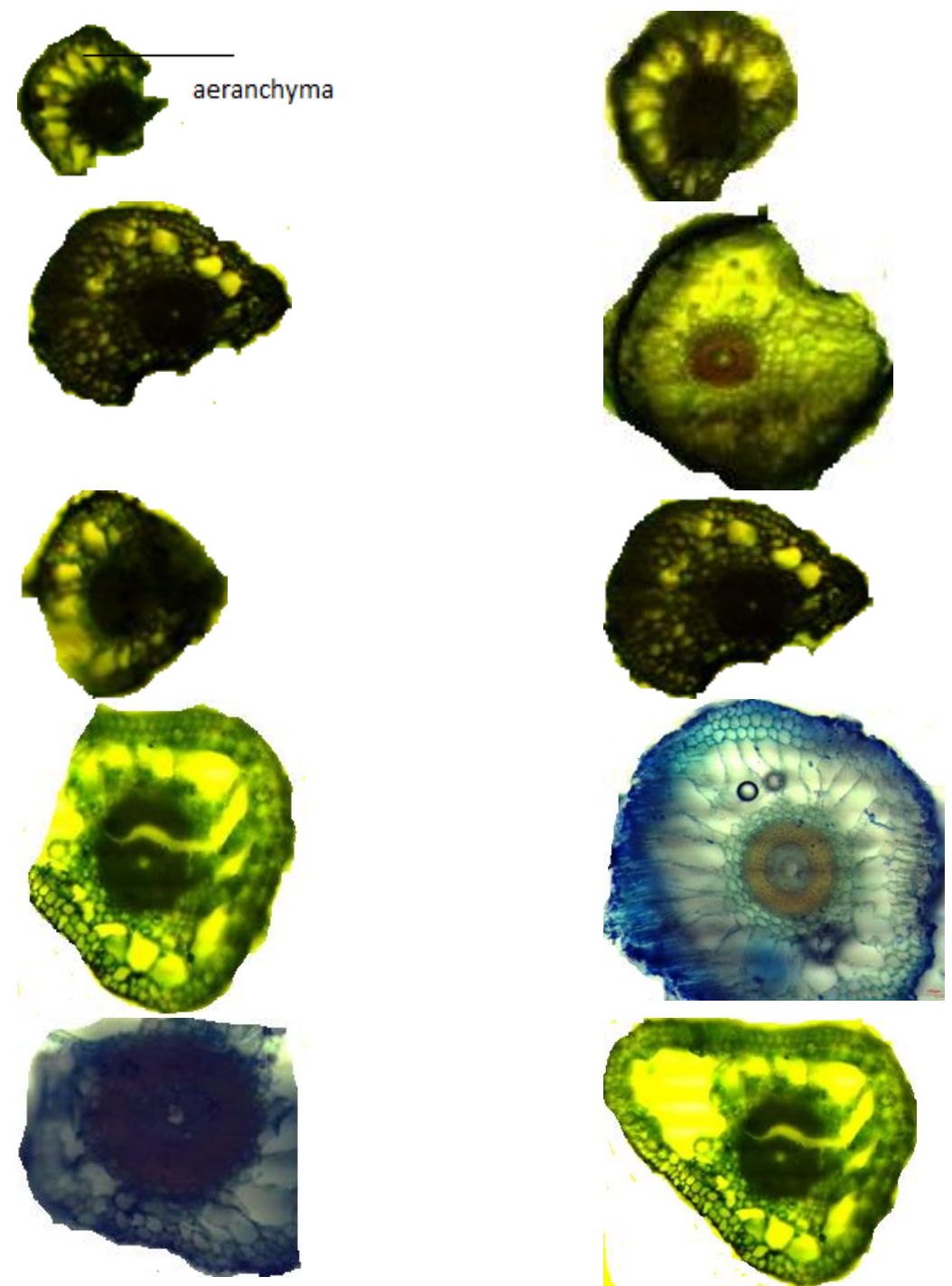

Figure 2 Aeranchyma formation of Puccinellia ciliata plants from different locations

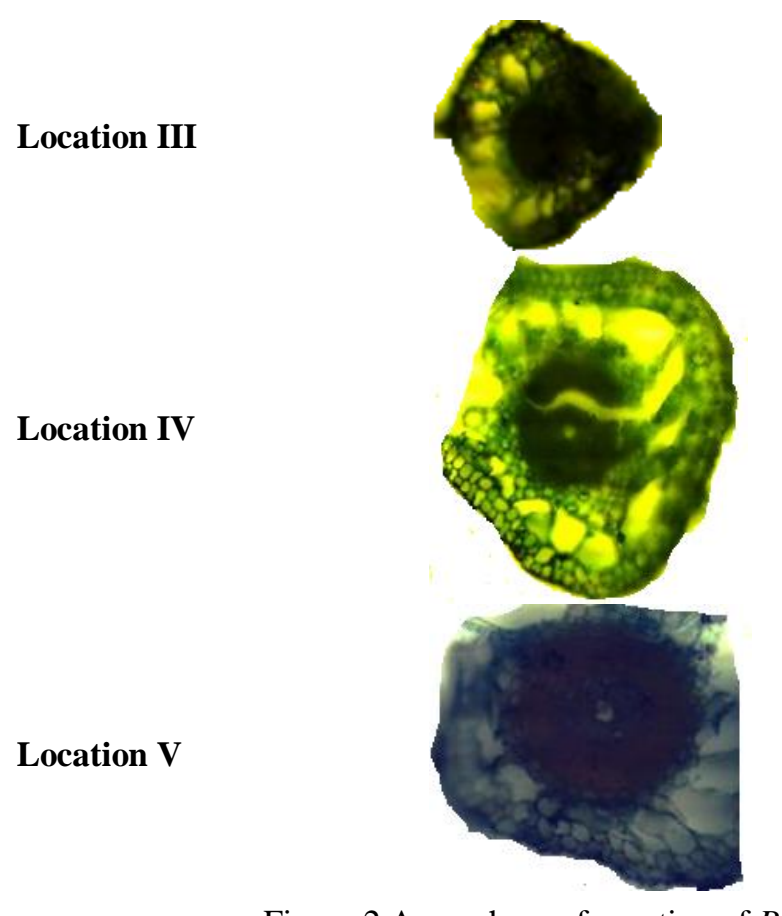

Plant Height, Green Herbage Yield and Hay Yield Values

According to Table 3 Average plant height and hay yield values were; 47.2 to $74.4 \mathrm{~cm}$. and 15.61 to 80.85 g/plant respectively. Highest plant hight obtained from Location I, however highest hay yield gained from Location V. We concluded that the plants on Location V can be considered as forage crops (Table 3 ).

\section{Adventitious Root Anatomy}

Adventitious root anatomy of Puccinellia ciliata Bor was evaluated and the pictures of roots from each location captured by a Novex B series 86041 Model Trinocular Microscope. Intensive aeranchyma formation on root tips can easily be recognised from the pictures on Figure 2.

We assessed aeranchyma formation type as radial lysigeny as seen on rice (Oryza sativa) relying on Jung et al. 2008. Lysigeny type of aeranchyma forms by programmed cell death under submergence conditions or whenever the soil is waterlogged, Puccinellia ciliata Bor roots can be able to adequetly respire because of its roots adaptaion to insufficient oxygen environment by this aeranchyma formation mechanism.

\section{Discussion}

Alkali grass is usually found on alkaline and strong alkaline soils (8.31-10.83) in Australia (Brown, 2004). These results parallel our findings. $\mathrm{pH}$ values of 10.39 and 10.83 in IV and V locations indicated that alkali grass can grow in strong alkaline areas. Brown (2004) determined that the EC values in the areas of alkali grass ranged from 9.7 to $41.0 \mathrm{dS} / \mathrm{m}$. It has been reported that the Menemen variety developed from alkali grass is grown in Australia with salinity of 10.0-40.0 dS/m (Barett-Lennard et al., 1999). Soil analysis results showed that all locations were in the unsalted class whereas $\mathrm{Na}$ values were in very high class. It was observed that the problem in these regions was especially sodium rather than salinity. Therefore alkali grass has been grown successfully in these areas. It was observed that the soil of the alkali grass is over-calcified and has moderate calcium content. alkali grass grows in areas with waterlogging and drainage problems. Setter et al. (2009) was indicated that waterlogging causes many changes in soil chemistry and particularly the amount of $\mathrm{Mn}$ and $\mathrm{Fe}$ exceeding the critical toxic level. It was observed that the alkali grass 
grows in very unfavorable conditions in our region, unlike the other regions. It was shown that the amount of Fe, Mn and B were high, sufficient and toxic, respectively in our region. Therefore using alkali grass, itself for phytoremediation and/or phytoextraction will remove excess boron from contaminated soil. Therefore this will be useful for soil depollution and for simple boron purification (Öztürk et al., 2017).

Table $2 \mathrm{Na}, \mathrm{K}, \mathrm{Ca}, \mathrm{Mg}$ and B contents per root, stem and cluster of plants from different locations

\begin{tabular}{|c|c|c|c|c|c|c|c|c|c|c|c|c|c|c|c|}
\hline \multirow[b]{2}{*}{$\mathrm{L}$} & \multicolumn{5}{|c|}{ Root } & \multicolumn{5}{|c|}{ Stem } & \multicolumn{5}{|c|}{ Cluster } \\
\hline & $\begin{array}{l}\mathrm{Na} \\
(\%)\end{array}$ & $\begin{array}{c}\mathrm{K} \\
(\%)\end{array}$ & $\begin{array}{c}\mathrm{Ca} \\
(\%)\end{array}$ & $\begin{array}{l}\mathrm{Mg} \\
(\%)\end{array}$ & $\begin{array}{c}\mathrm{B} \\
(\mathrm{ppm})\end{array}$ & $\begin{array}{l}\mathrm{Na} \\
(\%)\end{array}$ & $\begin{array}{c}\mathrm{K} \\
(\%)\end{array}$ & $\begin{array}{c}\mathrm{Ca} \\
(\%)\end{array}$ & $\begin{array}{l}\mathrm{Mg} \\
(\%)\end{array}$ & $\begin{array}{c}\mathrm{B} \\
(\mathrm{ppm})\end{array}$ & $\begin{array}{l}\mathrm{Na} \\
(\%)\end{array}$ & $\begin{array}{c}\mathrm{K} \\
(\%)\end{array}$ & $\begin{array}{c}\mathrm{Ca} \\
(\%)\end{array}$ & $\begin{array}{l}\mathrm{Mg} \\
(\%)\end{array}$ & $\begin{array}{c}\mathrm{B} \\
(\mathrm{ppm})\end{array}$ \\
\hline $\bar{I}$ & 0.24 & 0.18 & 0.74 & 0.74 & 449 & 0.09 & 0.89 & 0.18 & 0.26 & 64 & 0.03 & 0.35 & 0.14 & 0.34 & 169 \\
\hline II & 0.09 & 0.19 & 0.78 & 0.63 & 654 & 0.37 & 1.04 & 0.19 & 0.14 & 546 & 0.07 & 0.25 & 0.09 & 0.18 & 542 \\
\hline III & 0.26 & 0.16 & 0.66 & 0.72 & 802 & 0.16 & 0.96 & 0.20 & 0.27 & 425 & 0.07 & 0.29 & 0.12 & 0.25 & 502 \\
\hline IV & 0.20 & 0.19 & 1.13 & 0.70 & 1078 & 0.40 & 0.96 & 0.30 & 0.15 & 734 & 0.14 & 0.34 & 0.16 & 0.22 & 647 \\
\hline V & 0.15 & 0.16 & 0.85 & 0.70 & 938 & 0.26 & 0.81 & 0.26 & 0.16 & 816 & 0.07 & 0.30 & 0.18 & 0.26 & 794 \\
\hline $\mathrm{M}$ & 0.19 & 0.18 & 0.83 & 0.70 & 784 & 0.26 & 0.93 & 0.22 & 0.20 & 517 & 0.08 & 0.31 & 0.14 & 0.25 & 531 \\
\hline$\overline{S t} \cdot{ }_{E}$ & 0.031 & 0.007 & 0.081 & 0.019 & 109.45 & 0.059 & 0.039 & 0.023 & 0.028 & 132.5 & 0.018 & 0.018 & 0.016 & 0.026 & 103.59 \\
\hline $\mathrm{CV}$ & 36.74 & 8.62 & 21.66 & 5.94 & 31.21 & 51.87 & 9.27 & 22.91 & 32.39 & 57.30 & 52.30 & 13.19 & 25.31 & 23.66 & 43.64 \\
\hline
\end{tabular}

L: Locations

Table 3 Plant Height, Green Herbage Yield and Hay Yield values of five locations.

\begin{tabular}{|c|c|c|c|c|c|c|c|c|c|c|c|c|c|c|c|}
\hline \multirow{2}{*}{$\mathrm{R}$} & \multicolumn{3}{|c|}{ Location I } & \multicolumn{3}{|c|}{ Location II } & \multicolumn{3}{|c|}{ Location III } & \multicolumn{3}{|c|}{ Location IV } & \multicolumn{3}{|c|}{ Location V } \\
\hline & $\mathrm{PH}$ & GHY & HY & $\mathrm{PH}$ & GHY & HY & $\mathrm{PH}$ & GHY & $\mathrm{HY}$ & $\mathrm{PH}$ & GHY & $\mathrm{HY}$ & $\mathrm{PH}$ & GHY & HY \\
\hline 1 & 62 & 18,5 & 11,9 & 65 & 48,2 & 23,3 & 64 & 68,7 & 31,6 & 40 & 88,4 & 43,9 & 76 & 367,5 & 185,4 \\
\hline 2 & 67 & 15,1 & 7,6 & 65 & 33,1 & 17,4 & 70 & 42,9 & 20,0 & 58 & 53,9 & 38,8 & 61 & 89,8 & 49,2 \\
\hline 3 & 73 & 52,6 & 27,9 & 50 & 13,4 & 7,8 & 62 & 11,5 & 5,8 & 50 & 72,8 & 36,7 & 57 & 166,4 & 83,8 \\
\hline 4 & 70 & 10,2 & 6,8 & 40 & 3,5 & 3,0 & 86 & 108,3 & 54,9 & 59 & 47,3 & 29,1 & 50 & 279,5 & 148,9 \\
\hline 5 & 80 & 56,2 & 27,8 & 45 & 49,9 & 17,8 & 82 & 28,9 & 18,2 & 34 & 278,9 & 131,7 & 57 & 104,3 & 48,7 \\
\hline 6 & 87 & 62,4 & 32,6 & 45 & 11,3 & 7,6 & 69 & 68,7 & 31,6 & 39 & 75,8 & 28,3 & 70 & 50,4 & 27,6 \\
\hline 7 & 74 & 16,2 & 8,0 & 35 & 0,8 & 0,4 & 45 & 41,0 & 22,5 & 43 & 56,8 & 23,5 & 66 & 217,6 & 103,4 \\
\hline 8 & 77 & 81,3 & 36,9 & 33 & 2,6 & 0,8 & 69 & 92,6 & 43,6 & 48 & 201,3 & 96,6 & 41 & 28,8 & 15,5 \\
\hline 9 & 80 & 54,6 & 27,1 & 35 & 5,3 & 3,2 & 64 & 26,3 & 12,5 & 57 & 54,7 & 39,8 & 61 & 136,5 & 68,7 \\
\hline 10 & 74 & 22,2 & 12,9 & 59 & 143,9 & 74,8 & 73 & 75,4 & 42,8 & 51 & 71,9 & 28,9 & 68 & 150,9 & 77,0 \\
\hline$\overline{\mathrm{M}}$ & 74.4 & 38.9 & 19.9 & 47.2 & 31.2 & 15.6 & 68.4 & 56.4 & 28.4 & 47.9 & 100.2 & 49.8 & 60.7 & 159.2 & 80.8 \\
\hline St.E & 2.26 & 5.91 & 3.66 & 3.86 & 13.84 & 7.04 & 3.57 & 9.87 & 4.87 & 2.75 & 24.34 & 11.23 & 3.22 & 33.10 & 16.79 \\
\hline $\mathrm{CV}$ & 9.59 & 48.00 & 58.02 & 25.87 & 140.27 & 142.60 & 16.50 & 55.30 & 54.32 & 18.16 & 76.84 & 71.39 & 16.77 & 65.75 & 65.71 \\
\hline
\end{tabular}

R: Replication, M: Mean, PH: Plant Height; GHY: Green Herbage Yield; HY: Hay Yield

It was determined that the $\mathrm{K}$ accumulation in plants is the element showing the least variance between the locations in terms of root, stem and bunch. Similarly, Jenkins (2007) reported that the alkali grass increased the salinity and $\mathrm{Na}$ content of the growing media, but the $\mathrm{K}$ accumulation remained constant. The most variable elements in our study were $\mathrm{Na}$ and $\mathrm{B}$ in terms of all plant parts. $P$. distans has an efficient root B-exclusion capability and B tolerance in shoots (Hamurcu et al., 2016). Puccinellia distans was evaluated as a boron hyperaccumulator against high boron contents (Hamurcu et al., 2009; Öztürk et al., 2017; Stiles et al., 2010). When the "Translocation Factor" (TF) evaluated as shoot / root content and values above 1.0 are considered as hyperaccumulators; the TF value in plants was found to be less than 1.0 in soil containing high lime, medium calcium and very high magnesium. The dry matter average production of alkali grass is 3-7.5 ton $/ \mathrm{ha}^{-1}$ (Changgui and Shuning, 1992). Dry hay yields of halophyte species in saline grasslands were significantly different among species. The differences could be due to the the genetic structures, genotype or species because of the physiological and biological properties, root structure and habitat (Temel et al., 2015). The aerenchyma tissue we observed was similar to the radial lysigeny (RL) aerenchyma type which schizogenous separations are accompanied or followed by collapse and death of cells along radial sectors of the mid cortex found by Jung et al. (2008) (Figure 2).

In Aydın, alkali grass plants are usually found in toxic areas of boron, low organic matter, extremely alkaline and sodium, waterlogged soils. Overall, considering the results of this study, it could be concluded that alkali grass can be suggested as a hyperaccumulator plant by the combination of more favourable characteristics are salt tolerance, waterlogging tolerance, high EC range, suitable for adverse environmental conditions, high biomass value and convincing nutritive value. These species can play also a significant role as an alternative forage resource in recovered of the grazing lands losing the production potential due to unconscious utilization and salinity. For this purpose, the plants in the fifth localition can be used as feed in these areas. 


\section{Acknowledgements}

We thank the Projects of Scientific Investigation of Adnan Menderes University for funding (Project number: ZRF-14003). The authors are very thankful to Prof.Dr. Özhan Boz for diagnosis of Puccinellia.

\section{References}

Açıkgöz N, Akbaş ME, Moghaddam A, Özcan K. 1994. PC'ler için veri tabanı esaslı Türkçe İstatistik Paketi: TARİST. 1. Tarla Bitkileri Kongresi, İzmir, 24-28.04.1994. Ege Üni. Zir.Fak. Ofset Basımevi, pp: 264- 267.

Barrett-Lennard EG, van Ratingen P, Mathie MH. 1999. The developing pattern of damage in wheat (Triticum aestivum L.) due to the combined stresses of salinity and hypoxia: experiments under controlled conditions suggest a methodology for plant section. Australian Journal of Agricultural Research, 50:129-136.

Brown AJ. 2004. Exotic and native Puccinellia species in Victorien saline landspaces. In "Salinity Solutions". Proceedings of the Salinity Solutions Conference "Working with Science and Society" 2-5 August 2004, Bendigo, Victoria, Eds: Ridley, A., Feikama, P., Bennett, S., Rogers, M.J., Wilkinson, R. And Hirth, J. (CRC for Plant-Based Management of Dryland Salinity:Perth).

Changgui W, Shuning T. 1992. Surveys, standards, and classification schemes. Chapter 6. Gansu and Qinghai. Grasslands and Grassland Sciences in Northern China. Washington, DC: The National Academies Press. doi: $10.17226 / 1942$

Hamurcu M, Gezgin S, Turkan I, Hakki E, Soylu S, Yorgancilar M. 2009. Makarnalik Bugday Cesitleri (Triticum durum) ile Corak Cimi'nde (Puccinellia distans) Bor Toksisitesinin Temel Fizyolojik ve Biyokimyasal Ozelliklere Etkisinin Belirlenmesi. TOVAG-1080559 Project Final Report, Turkiye Bilimsel ve Teknik Arastirma Kurumu, Ankara. http://goo.gl/bW2qz

Hamurcu M, Hakki EE, Demiral Sert T, Bell RW. 2016. Extremely high boron tolerance in Puccinellia distans (Jacq.) Parl. related to root boron exclusion and a well-regulated antioxidant system. Zeitschrift fur Naturforschung C, 71(7).

Jenkins S. 2007. Ecophysiological Principles Governing the Zonation of Puccinellia (Puccinellia ciliata Bor) and Tall Wheatgrass (Thinopyrum ponticum) on Saline Waterlogged Land in South-western Australia. PhD Thesis. University of Western Australia, Perth, Western Australia

Jung J, Lee SC, Choi HK. 2008. Anatomical patterns of aerenchyma in aquatic and wetland plants. J Plant Biol., 51:428-439. doi: 10.1007/BF03036065

Kachout SS, Leclerc JC, Mansoura AB, Rejeb MN, Ouerghi Z. 2009. Effects of heavy metals on growth and bioaccumulation of the annual halophytes Atriplex hortensis and A. rosea. J. Appl. Sci. Res., 5:746-756.
Kutty AA, Al-Mahaqeri SA. 2016. An Investigation of the Levels and Distribution of Selected Heavy Metals in Sediments and Plant Species within the Vicinity of Ex-Iron Mine in Bukit Besi. J. of Chem., Article ID 2096147, 12 pages, doi: $10.1155 / 2016 / 2096147$

LeDuc DL, Terry N. 2005. Phytoremediation of toxic trace elements in soil and water. Journal of Industrial Microbiology \& Biotechnology, 32:514-520.

Marques APGC, Rangel AOSS, Castro PML. 2009. Remediation of heavy metal contaminated soils: Phytoremediation as a potentially promising clean-up technology. Critical Reviews in Environmental Science and Technology, 39:622-654.

Nazir A, Malik RN, Ajaib M, Khan N, Siddiqui MF. 2011. Hyper accumulators of heavy metals of industrial areas of Islamabad and Rawalpindi Pakistan. J. Bot. 43(4): 1925-1933.

Öztürk SE, Göktay M, Has C, Babaoğlu M, Allmer J, Doğanlar S, Frary A. 2017. Boron Hyperaccumulation Mechanisms in Puccinellia distans as Revealed by Transcriptomic Analysis. 131. http://dx.doi.org/10.1101/110403

Paz-Ferreiro J, Lu H, Fu S, Mendez A, Gasco G. 2014. Use of phytoremediation and biochar to remediate heavy metal polluted soils: A review. Solid Earth, 5:65-75.

Pilon-Smits EAH. 2005. Phytoremediation. Ann. Rev. Plant Biol., 56:15-39.

Salt DE, Blaylock M, Kumar PBAN, Dushenkov V, Ensley BD, Chet L, Raskin L. 1995. Phytoremediation: A novel strategy for the removal of toxic metals from the environment using plants. Biotechnology, 13(2): 468-474.

Sarma H. 2011. Metal Hyperaccumulation in Plants: A Review Focusing on Phytoremediation Technology. Journal of Environmental Science and Technology, 4:118-138.

Setter TL, Burgress P, Waters I, Kuo J. 1999. Genetic diversity of barley waterlogging tolerance in Western Australia. Proceeding of the 9th Australian Barley Technical Symposium, Melbourne, Australia. 12-16 Sept. 1999.

Stiles AR, Bautista D, Atalay E, Babaoğlu M, Terry N. 2010. Mechanisms of boron tolerance and accumulation in plants: a physiological comparison of the extremely boron-tolerant plant species, Puccinellia distans, with the moderately borontolerant Gypsophila arrostil. Environ. Sci. Technol., 44:70897095 .

Temel S, Sürmen M, Tan M. 2015. Effects of Growth Stages on the Nutritive Value of Specific Halophyte Species In Saline Grasslands. The Journal of Animal \& Plant Sci., 25(5): 1419 1428.

Wolf R. 1971. The Determination of Boron in Soil Extractes Plant Materials Compost, Manures, Waters and Nutrient Solutions. Soil Sci. and Plant Anal., 2(5): 263-374 